\title{
DEWAN DIREKSI, DEWAN KOMISARIS TERHADAP NILAI PERUSAHAAN KONSUMSI : TOP 20 PERUSAHAAN TERDAFTAR DI BEI
}

\author{
Hurian Kamela ${ }^{1 *}$ \\ ${ }^{1}$ Pascasarjana Ilmu Akuntansi, Universitas Indonesia \\ email: melakame193@gmail.com
}

\begin{abstract}
The board of directors and commissioners are parties who play a role in the company, especially in corporate decision making. The main objective of this research is to analyze the number of boards of directors and commissioners of firm value. The number of samples based on this study were 20 companies for 4 years (20142017). The total sample is 80 observations. The reason the sample was chosen because of the large consumption reasons that had a reputation and were well known in the community. The method used is multiple regression. The dependent variable for the use of measurement that is often used is Tobins-q. The independent variable is based on the measurement of the board of directors and the measurement of the board of commissioners in the company. In addition to this research, the control variables used were Return On Assets (ROA) and total assets. The results of the study explain that there is no effect of the two hypotheses of the board of directors and the board of commissioners on firm value. In general, the number of company leaders has no effect on company activities. The leader of the company has been carrying out its role as a board of monitoring. The contribution of the research is that companies that have carried out good evaluation and selection to increase firm value by implementing the board of directors and commissioners according to the standards.
\end{abstract}

Keywords: Company; Board; Directors; Commissioner.

\begin{abstract}
ABSTRAK
Dewan direksi dan komisaris merupakan pihak yang berperan dalam perusahaan, khususnya pengambilan keputusan perusahaan. Tujuan utama penelitian untuk menganalisis mengenai jumlah dewan direksi dan komisaris terhadap nilai perusahaan. Jumlah sampel berdasarkan penelitian ini adalah 20 buah perusahaan konsumsi selama 4 tahun yaitu 2014-2017. Total sampel adalah 80 observasi. Alasan sampel ini dipilih karena merupakan perusahaan konsumsi besar yang telah memiliki reputasi dan sudah dikenal di masyarakat. Metode yang digunakan adalah regresi berganda. Variabel dependen menggunakan pengukuran yang sering digunakan yaitu Tobins-q. Variabel independen berdasarkan pengukuran dewan direksi serta pengukuran dewan komisaris pada perusahaan. Sebagai tambahan dari penelitian ini digunakan variabel kontrol yaitu Return On Asset (ROA) dan total aset. Hasil penelitian menjelaskan tidak ada pengaruh dari 2 hipotesis yaitu dewan direksi serta dewan komisaris terhadap nilai perusahaan. Secara kuantitatif, jumlah dari pemimpin perusahaan tidak berpengaruh terhadap kegiatan perusahaan. Pemimpin perusahaan telah menjalankan perannya sebagai dewan untuk melakukan monitoring. Kontribusi penelitian bahwa perusahaan yang terdaftar telah melakukan evaluasi dan seleksi yang baik untuk meningkatkan nilai perusahaan dengan melakukan pemilihan pihak direksi dan komisaris yang sesuai standar.
\end{abstract}

Kata Kunci: Perusahaan; Dewan; Direksi; Komisaris. 


\section{PENDAHULUAN}

Dewan direksi (BOD) dan Dewan komisaris (BOC) merupakan pihak yang terlibat di dalam perusahaan sektor privat. Sebagian besar perusahaan telah menunjukkan secara rinci jumlah dewan direksi dan dewan komisaris yang tercantum dalam laporan keuangan resmi seperti yang terpublikasi di BEI. Kirchmaier \& Grant (2005) menjelaskan bahwa dewan direksi menjadi mekanisme utama dalam melakukan kontrol, khususnya dalam melakukan kontrol terhadap direktur institusional. Direktur mempunyai peran utama dalam posisinya di dewan yaitu sebagai perwakilan dari kepentingan pemegang saham (besar) dan investor institusional untuk melindungi kepentingan bersama. Hal ini diperjelas dengan pernyataan bahwa investor institusi merupakan pemegang saham pengendali yang sangat penting serta berpartisipasi aktif sebagai direktur di dewan direksi (Nekhili \& Gatfaoui 2013; Giner dan Pardo 2015). Penelitian sebelumnya mengenai dewan di luar negeri juga diteliti oleh Thompson et. al (2019) yang menjelaskan bahwa pelaksanaan serta voting pemilihan anggota dewan pada perusahaan milik negara (BUMN) di Barbados samgat berhubungan dengan koneksi politik, sehingga dapat mengurangi sikap independensi dewan, posisi ini sangat nerpengaruh terhadap pelaksanaan kegiatan. Hal ini berbeda di perusahaan, karena perusahaan mencerminkan transparansi dan akuntabilitas, sehingga memilih anggota dewan berdasarkan kompetensi, kualitas serta pengalaman yang ada. Deschênes, S. et al. (2014) membahas mengenai CEO compensation, BOD dan nilai perusahaan di perusahaan besar Kanada, hasilnya membuktikan bahwa ada pengaruh positif antara CEO terhadap nilai valuasi di perusahaan, khususnya pada investor. Ini menunjukkan peran bahwa petinggi di perusahaan memiliki peranan penting dalam menunjang kegiatan utama/ operasi di perusahaan. Berdasarkan hal diatas, sangat jelas bahwa peran direksi maupun komisioner merupakan tonggak utama di perusahaan. Jumlah direksi dan komisaris di perusahaan menjelaskan seberapa besar posisi petinggi perusahaan dalam meningkatkan valuasi (nilai) khususnya pada pihak outsider.

Penelitian Dewan direksi (BOD) dan Dewan komisaris (BOC) akan memberikan analisis secara kuantitatif, seperti penjelasan mengenai seberapa besar peran anggota dewan baik itu direksi atau komisaris pada perusahaan konsumsi di Indonesia. Penelitian sebelumnya oleh Suhardjanto et al. (2017) yang membahas mengenai dewan direksi, komisaris yang dikaitkan dengan audit pada perusahaan minyak dan gas sedangkan pada penelitian ini memberikan perbedaan yaitu (1) menambahkan pengukuran variabel kontrol yaitu Return On Asset (ROA) dan total aset (ln) sehingga lebih spesifik dalam pengukuran keuangan terhadap nilai perusahaan, (2) sampel yang diambil adalah perusahaan konsumsi (top 20) yang terdaftar di IDX. Kontribusi penelitian ini memberikan gambaran mengenai 3 hal yaitu (1) memberikan pembahasan nilai perusahaan dalam sektor konsumsi, (2) membuktikan apakah peran variabel kontrol seperti ROA dan total aset dapat berpengaruh terhadap nilai perusahaan, sehingga hasil yang didapat bisa menjadi lebih akurat.

\section{KAJIAN LITERATUR}

Teori Agensi

Teori agensi merupakan salah satu teori yang berhubungan dengan pihak-pihak (individu) di perusahaan. Acero \& Alcalde (2016) bahwa posisi BOD dapat mengurangi agency problem yaitu antara shareholder dan manajer (agensi tipe 1), tetapi juga mengatasi permasalahan antara mayoritas dan minoritas shareholder 
(agensi tipe 2) sehingga peran utama dari dewan direksi (BOD) bertanggungjawab untuk memegang monitor serta mencegah perilaku oportunistik dalam melindungi minoritas shareholder. Hal ini juga dijelaskan oleh Cueto (2013) bahwa pencegahan perilaku oportunistik dapat dikendalikan jika agency problem telah terlaksana dengan baik.

Nilai Perusahaan (Tobins'q)

Merupakan pengukuran nilai keuangan yang sering digunakan, seperti oleh Smithson, C. W., \& Simkins, B. J. (2005) bahwa nilai perusahaan menggambarkan kondisi dan risiko dalam perusahaan. Penelitian McShane (2011) mengenai risiko dan nilai perusahaan menggunakan pengukuran firm value untuk menilai kondisi perusahaan berdasarkan aspek finansial.

Tobinsq = Market value of equity + the book value of liabilities / the book value of asset

\section{Board Of Director (BOD)}

Board Of Director (BOD) disebut dengan dewan direksi merupakan pihak yang terlibat dalam perusahaan. Lozano et al. (2017) yang melakukan penelitian di Spanyol menjelaskan mengenai peran dewan direksi untuk menciptakan transparansi, supaya memastikan lingkungan perusahaan telah berjalan sesuai prosedur dan kontrol telah dijalankan. Desjardins and Willis (2009) juga menjelaskan bahwa BOD bertanggungjawab terhadap pengelolaan manajemen risiko serta pelaksanaan laporan, khususnya keuangan.

\section{Board Of Commisioner (BOC)}

Zulfikar et al. (2017) menjelaskan bahwa BOC merupakan pihak supervisor yang melakukan kontrol terhadap pihak manajemen, sehingga memiliki peran yang sangat berpengaruh di perusahaan. Hal ini juga dibuktikan oleh Suhardjanto et al. (2017) membahas mengenai diversitas dan pengaruh dewan komisaris terhadap pengukuran kinerja keuangan. Hasilnya bahwa hanya faktor background pendidikan dari dewan komisaris yang berpengaruh positif terhadap kinerja keuangan. Pengukuran jumlah komisaris berdasarkan jumlah BOC perusahaan setiap tahunnya.

\section{Return On Assets (ROA)}

Hull and Rothenberg (2008) menjelaskan bahwa ROA merupakan pengukuran keuangan (rasio) untuk mengukur efektivitas serta perputaran dalam keuangan. Pengukuran ini sering digunakan karena merupakan variabel yang efektif dalam menentukan informasi secara langsung mengenai alokasi sumber daya keuangan yang dimiliki perusahaan secara menyeluruh.

Total Asset (Ln)

Guido (2018) menjelaskan bahwa posisi aset dalam finansial adalah salah satu komponen moneter dalam perusahaan, khususnya dalam "money supply" atau penawaran keuangan, selain itu aset juga menggambarkan penentuan kemampuan perusahaan dalam mengelola risiko yang terjadi. Oleh karena itu diambil total aset sebagai variabel kontrol dengan rumus :

Asset $=$ Logaritma Natural (Ln) total aset periode 1 tahun.

\section{Hipotesis}

Suhardjanto et al. (2017) membahas mengenai pihak dewan direksi serta pihak dewan komisaris pada perusahaan minyak dan gas, hasilnya memberikan kesimpulan bahwa dewan direksi mempunyai pengaruh positif terhadap nilai perusahaan. Penelitian Setiany E. (2019) membahas mengenai dewan direksi wanita juga berpengaruh positif terhadap nilai perusahaan di perusahaan manufaktur, sehingga hipotesisnya adalah :

H1 = BOD $($ Dewan Direksi) Berpengaruh Positif Terhadap Nilai Perusahaan Sektor Konsumsi. 
Suhardjanto et al. (2017) juga menggunakan dewan komisaris terhadap nilai perusahaan dengan sub-sektor yamng berbeda, yaitu perusahaan minyak dan gas, penjelasannya adalah dewan komisaris berpengaruh positif terhadap nilai perusahaan. Westphal, J. D. \& Zajac (1994) menjelaskan keefektifan dewan akan meningkatkan kegiatan yang akan dilakukan perusahaan untuk masa yang akan datang. Penelitian ini menggunakan sektor yang berbeda yaitu perusahaan konsumsi, sehingga hipotesisnya adalah :

\section{$\mathrm{H} 2=$ BOC (Dewan Komisaris) Berpengaruh Positif Terhadap Nilai Perusahaan Sektor Konsumsi.}

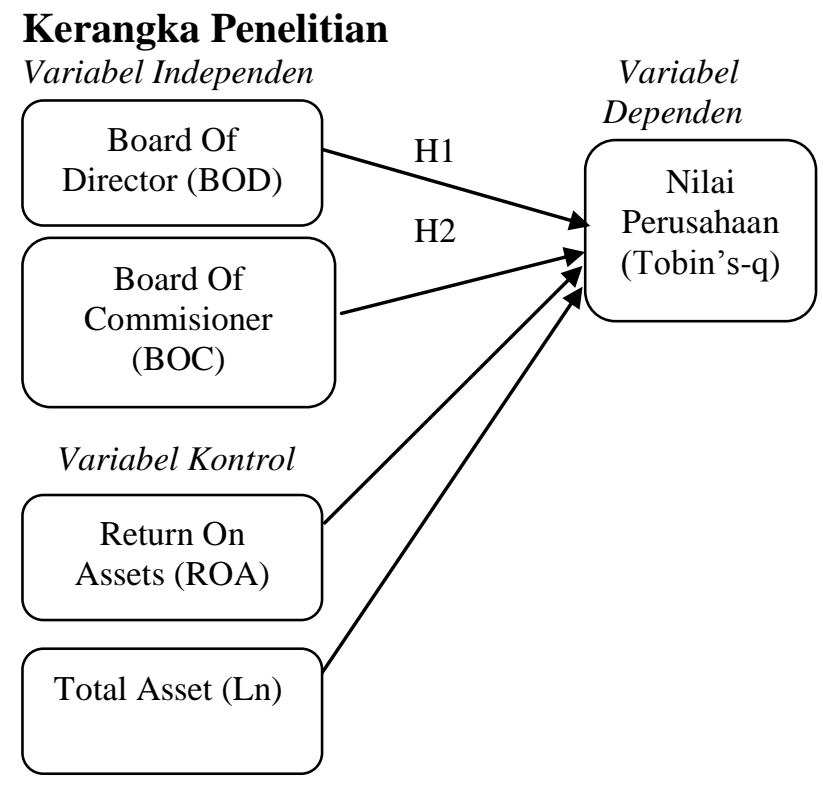

Gambar 1. Kerangka Penelitian

\section{METODE PENELITIAN}

Penelitian ini menggunakan sampel 20 perusahaan konsumsi yang terdaftar pada Bursa Efek Indonesia (BEI) dengan jangka waktu (periode) 4 tahun 2014-2017. Total keseluruhan observasi adalah 80 perusahaan. Metode yang dipilih adalah regresi berganda dengan menggunakan software stata 14.

Pengumpulan data adalah berdasarkan data sekunder yaitu berdasarkan laporan keuangan perusahaan yang terdaftar pada masing-masing perusahaan. Data tambahan sekunder untuk tobins-q yaitu market book value (MBV) didapatkan dari database stream yaitu thomson reuters eikon.

Rumus :

TOBINSQ ${ }_{i t}=\alpha_{i t}+\beta 1$ BODSIZE $_{i t}+\beta 2$ BOCSIZE $_{i t}+\beta 3$ ROA $_{i t}+\beta 4$ ASSET $_{i t}$ + eit (1)

Keterangan :

Tobins- $\mathrm{q}=$ nilai perusahaan, $\mathrm{BODSIZE}=$ ukuran dewan direksi, BOCSIZE= ukuran dewan komisaris, $\mathrm{ROA}=$ rasio perputaran aset, ASSET $=$ total aset (alogaritma natural).

\section{HASIL DAN PEMBAHASAN}

Tabel 1. Statistik Deskriptif

\begin{tabular}{|c|c|c|c|c|}
\hline Variable & Mean & Std. Dev & Min & Max \\
\hline tobinsq & 3.038962 & 4.03739 & .3646072 & 19.75454 \\
\hline bodsize & 5.45 & 2.175235 & 1 & 10 \\
\hline bocsize & 3.9875 & 1.47119 & 2 & 8 \\
\hline roa & 8.555608 & 10.60848 & 14.76728 & 43.92744 \\
\hline asset & 28.77177 & 1.612503 & 25.72043 & 32.15098 \\
\hline
\end{tabular}

Sumber: Data diolah, 2020

Tabel 1 menjelaskan tentang statistik deksriptif. Tobins-q dari tabel diatas menjelaskan nilai rata-rata dengan skor 3.038962. Rata-rata Bodsize sebanyak 5 orang dan Bocsize 3 orang (dibulatkan). Untuk ROA dan asset meannya masingmasing sebesar 8.555608 dan 28.77177.

Tabel 2. Hasil Regresi

\begin{tabular}{|c|c|c|c|c|c|}
\hline Variable & Coef. & $\mathbf{t}$ & P>t & Result & Hypoteses \\
\hline Cons_ & -3.76827 & -0.54 & 0.588 & No & \\
\hline bodsize & .2713511 & 1.35 & 0.180 & No & $\begin{array}{c}\text { H1 } \\
\text { (Rejected) }\end{array}$ \\
\hline bocsize & -.2169534 & -0.78 & 0.435 & No & $\begin{array}{c}\text { H2 } \\
\text { (Rejected) }\end{array}$ \\
\hline roa & .2591133 & 8.30 & 0.000 & Effect & No \\
\hline asset & .1382118 & 0.52 & 0.608 & & \\
\hline Prob>F & 0.000 & & & \\
\hline $\begin{array}{l}\text { R- } \\
\text { Square }\end{array}$ & 0.545 &
\end{tabular}

Sumber: Data diolah, 2020 
Tabel 2 menjelaskan tentang hasil regresi dari penelitian ini. Bodsize menunjukkan hasil 0.180 (lebih besar >0.05) memberikan bukti bahwa dewan direksi tidak juga berpengaruh terhadap nilai perusahaan. BOC size juga menunjukkan hasil 0.435 (lebih besar >0.05) juga memberikan bukti bahwa dewan komisaris tetap tidak berpengaruh terhadap nilai perusahaan dalam penelitian ini. Hasil memberikan bukti secara kuantitatif yang agak berbeda dengan penelitian sebelumnya. $\mathrm{H} 1$ dan $\mathrm{H} 2$ tidak diterima karena BOD atau BOC tidak memiliki pengaruh terhadap nilai perusahaan.

Pembahasan $\mathrm{H} 1$ pada penelitian ini juga memberikan hasil yang berbeda yaitu rejected. Hal ini berbeda dengan Suhardjanto et al. (2017) yang membahas bahwa peran direksi berpengaruh terhadap nilai perusahaan di Indonesia dan Pakistan, sedangkan pada $\mathrm{H} 1$ penelitian ini menjelaskan posisi direksi tidak terlalu dominan di perusahaan, hal ini karena posisi direksi di Indonesia kebanyakan bersifat tetap dalam periode yang sama, khususnya pada perusahaan besar yang diteliti dengan sampel yang terbatas. Penelitian ini membuktikan semakin banyak jumlah direksi, nilai perusahaan bersifat fixed (tetap) dapat disebabkan oleh : (1) berbedanya pola budaya perusahaan besar (top 20) dibandingkan dengan perusahaan dengan skala yang lebih kecil, (2) perusahaan besar cenderung stabil dalam melakukan tata kelola (governance) yang lebih terukur sesuai dengan standar yang berlaku sehingga jumlah direksi tidak akan berpengaruh secara signifikan. $\mathrm{H} 2$ pada penelitian ini juga memberikan hasil yang berbeda yaitu rejected, hal ini memberikan penjelasan yang kurang lebih sama peran dengan direksi (BOD), bahwa peran komisaris (BOC) di perusahaan besar di Indonesia tidak mempengaruhi kinerja (ROA) tetap stabil.

Variabel kontrol yaitu ROA berpengaruh terhadap nilai perusahaan dengan skor sebesar 0.000, sedangkan variabel asset sebesar 0.608 tidak berpengaruh terhadap nilai perusahaan.

Tabel 3. VIF

\begin{tabular}{|c|c|}
\hline Variable & VIF \\
\hline bodsize & 1.93 \\
\hline bocsize & 1.89 \\
\hline roa & 1.67 \\
\hline asset & 1.11 \\
\hline Mean & 1.65 \\
\hline
\end{tabular}

Sumber: Data Diolah, 2020

Tabel 3 menjelaskan tentang VIF (asumsi multikolinearitas). Tertinggi adalah Bodsize sebesar 1.93 dan terendah adalah asset yaitu 1.11. Rata-rata VIF adalah 1.65, hal ini membuktikan bahwa bebas multikolinearitas.

\section{KESIMPULAN DAN SARAN}

Penelitian ini membuktikan secara kuantitatif bahwa posisi individu/ kelompok di perusahaan yaitu Dewan direksi (BOD) dan Dewan komisaris (BOC) tidak memiliki pengaruh apapun terhadap nilai perusahaan yang diukur melalui tobins'q. Hasil penelitian ini memberikan penjabaran secara kuantitatif bahwa pelaksanaan perusahaan tetap berjalan semestinya, tidak ada pengaruh posisi dewan terhadap nilai perusahaan (kedua hipotesis tidak di terima). ROA sebagai variabel kontrol yang berpengaruh terhadap nilai perusahaan. Perusahaan yang terdaftar telah melakukan evaluasi dan seleksi yang baik untuk meningkatkan nilai perusahaan dengan melakukan pemilihan pihak direksi dan komisaris yang sesuai standar. Hasil penelitian yang berbeda dengan penelitian sebelumnya dapat disebabkan karena 3 hal yaitu (1) jumlah sampel yang terbatas karena menggunakan 20 sampel perusahaan saja, (2) jenis perusahaan di Indonesia rata-rata berjumlah direksi yang stabil dan tetap (setiap tahunnya), (3) perbedaan governance perusahaan, karena perusahaan pada penelitian sebelumnya 
rata-rata menggunakan pengukuran perusahaan manufaktur/ industri yang lebih beragam. Keterbatasan dalam penelitian ini yaitu (1) dapat menggunakan rentang waktu dengan periode signifikan (before-after regulations) serta lebih panjang, misalnya 10 tahun, (2) dapat menggunakan sampel-sampel negara lain seperti ASEAN G-4 dengan currency keuangan yang disesuaikan (misal dalam satuan keuangan dollar US bukan dalam bentuk rupiah).

\section{DAFTAR PUSTAKA}

Acero, I., \& Alcalde, N. (2016). Controlling shareholders and the composition of the board: Special focus on family firms. Review of Managerial Science, 10(1), 61-83.

Cueto, D. (2013). Substitutability and complementarity of corporate governance mechanisms in Latin America. International Review of Economics and Finance, 25, 310325

Deschênes, S. et al. (2014). CEO' S Share Of Top Management Compensation, Characteristics Of The Board Of Directors And FirmValue Creation, Academy of Strategic Management Journal, Volume 13, Number 1, 57-74.

Desjardins, J., Willis, A., (2009). Climate Change Briefing: Questions for Directors to Ask. Available at: http://www.transformgcc.com/reso urces/CICA_Briefings/Climate\%20 Change.pdf.

Giner, B., \& Pardo, F. (2015). How ethical are managers' goodwill impairment decisions in Spanish-listed firms? Journal of Business Ethics, 132(1), 21-40.
Guido, J. (2018). Financial asset valuations: The total demand approach. The Quarterly Review of Economics and Finance. QUAECO-1195; No. of Pages 9. https://doi.org/10.1016/j.qref.2018. 11.004

Hull, C. E., and Rothenberg, S. (2008). "Firm Performance: The Interactions of Corporate Social Performance With Innovation and Industry Differentiation". Strategic Management Journal, 29(7): 781789.

Kirchmaier, T., \& Grant, J. (2005). Corporate ownership structure and performance in Europe. European Management Review, 2(3), 231245.

Lozano, M. B., Fuente, J. A., \& García-s, I. M. (2017). The role of the board of directors in the adoption of GRI guidelines for the disclosure of CSR information, 141 . https://doi.org/10.1016/j.jclepro.2016. 09.155

McShane, M. K., Nair, A., \& Rustambekov, E. (2011). Does enterprise risk management increase firm value? Journal of Accounting, Auditing and Finance, 26(4), 641-658. https://doi.org/10.1177/0148558X1 1409160

Nekhili, M., \& Gatfaoui, H. (2013). Are demographic attributes and firm characteristics drivers of gender diversity? Investigating women's positions on French boards of directors. Journal of Business Ethics, 118(2), 227-249 
Setiany, E. (2019). GENDER DIVERSITY AND FIRM VALUE : A STUDY On BOARDS OF PUBLIC MANUFACTURING. https://doi.org/10.21511/ppm.15(31).2017.11

Smithson, C. W., \& Simkins, B. J. (2005). Does risk management add value? A survey of the evidence. Journal of Applied Corporate Finance, 17, 8-17.

Suhardjanto, D., Alwiyah, A., Utami, M. E., \& Syafrudin, M. (2017). Board of Commissioners Diversity and Financial Performance: A Comparative Study of Listed Mining Industry in Indonesia and Pakistan. Review of Integrative Business \& Economics, 6 (Supplementary Issue 1), 131-142.

Thompson, R. M., Alleyne, P. and Charles-Soverall, W. (2019). Exploring governance issues among boards of directors within state-owned enterprises in Barbados, International Journal of Public Sector Management 32(3): 264-281.

Westphal, J. D. \& Zajac, E. J. (1994). Substance and symbolism in CEOs' long-term incentive plan. Administrative Science Quarterly, 39(3), 367-390.

Zulfikar, R., N. May, Suhardjanto, D., and Agustiningsih, S. W. (2017). "Independence commissioner against mandatory disclosure of financial performance as a moderating variable". Review of Integrative Business \& Economics Research, 6(3): 205-216 